\title{
IDENTIFIKASI POTENSI PENGEMBANGAN OBJEK WISATA ALAM DANAU PICUNG DITINJAU DARI ASPEK PRODUK WISATA DI MUARA AMAN PROVINSI BENGKULU
}

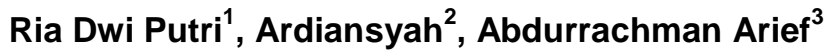 \\ ${ }^{1,2,3}$ Prodi Arsitekur, Teknik, Universitas Sriwijaya, JL.Srijaya Negara Bukit Besar Palembang,30128 \\ ${ }^{*}$ Riadwiputri89@gmail.com
}

\begin{abstract}
ABSTRAK. Danau Picung merupakan objek wisata alam yang terletak di Muara Aman Kabupaten Rejang Lebong Provinsi Bengkulu yang memiliki potensi dan keindahan alam yang sangat menarik. Objek wisata alam danau Picung dilihat dari produk wisata ( atraksi, amenitas, aksesibilitas ) masih belum berkembang dengan baik. Hal ini bisa dilihat dari pola penataan fasilitas sarana dan prasarana belum tertata dengan baik serta jumlah nya masih sangat sedikit sehingga kunjungan wisatawan belum maksimal. Penelitian ini menggunakan metode diskriptif kualitatif. Analisis yang digunakan dalam penelitian ini adalah analisis SWOT (strenght, weakness, opportunity, theart). Penelitian ini bertujuan untuk mengetahui potensi obyek wisata alam danau Picung ditinjau dari aspek produk wisata, menganalisis strategi pengembangan obyek wisata alam danau Picung terkait aspek produk wisata, dan mengetahui rencana pengembangan dan arahan desain zonasi kawasan objek wisata alam Danau Picung. Potensi yang bisa dikembangkan di danau Picung adalah sebagai wisata alam dan rekreasi yang memiliki perbedaan keindahan dan keunikan dari objek wisata yang lainnya. Strategi pengembangan kawasan wisata alam danau Picung dengan peningkatan atraksi budaya, atraksi buatan, dan atraksi alam serta amenitas yang memiliki potensi keaslian dan keunikan yang menarik, serta peningkatan SDM di daerah sekitar kawasan objek wisata dengan memberikan pembinaan dan pelatihan sehingga bisa meningkatkan kompetensi. Program pengembangan produk wisata adalah pengembangan atraksi wisata agro, wisata fauna (Kebun binatang, kolam pemancingan), outbond, waterpark, taman hiburan, taman bunga, atraksi kereta gantung, perahu bebek, festival budaya, kesenian dan kerajinan khas ( souvenir ). Pengembangan amenitas hotel/ resort terapung, restoran terapung, pusat informasi wisatawan, toilet, mushola, kios souvenir, gazebo, loket. Peningkatan kualitas aksesibilitas dengan menjaga kondisi jalan dan dibuat sarana transportasi umum.
\end{abstract}

Kata kunci: Produk Wisata, Potensi Wisata Alam, Danau Picung

ABSTRACT. Lake Picung is a natural tourist attraction located in Muara Aman Rejang Lebong District Province Bengkulu which has the potential and natural beauty that is very interesting. Lake Picung's natural attractions seen from tourism products (attractions, amenities, accessibility) are still not well developed. This condition can be seen from the arrangement of facilities and infrastructure facilities that have not been well organized, and the amount is still minimal so that tourist visits have not been maximum. This research uses a qualitative descriptive method. The analysis used in this research is a SWOT analysis (strength, weakness, opportunity, threat). This research aims to determine the potential of Lake Picung's natural attractions in terms of aspects of tourism products, analyzing the strategy of developing Lake Picung's natural attractions in terms of tourism products and find out about the development plan and direction of zoning design in the area of Lake Picung's natural tourism. The potential that can be developed in Lake Picung is as a natural and recreation tourism that has differences in the beauty and uniqueness of other tourist objects. The strategy for improving the natural tourist area of Lake Picung with the increase of cultural attractions, human-made attractions, and natural attractions and amenities that have the potential for authentic and exciting uniqueness, and increasing human resources in the area around the tourist attraction area by providing coaching and training so that it can improve competence. Tourism product development programs are the development of agro-tourism attractions, fauna tourism (zoos, fishing ponds), outbound, waterpark, recreation park, flower garden, attractions of cable cars, duck boats, cultural festivals, distinctive arts and crafts (souvenirs). Development of hotel/resort amenities, floating restaurants, tourist information centers, toilets, prayer rooms, gazebos, the place to buy an entrance ticket. They are improving accessibility quality by maintaining road conditions dan making public transportation facilities.

Keywords: Tourism Product, Nature Tourism Potential, Lake Picung 


\section{PENDAHULUAN}

Sektor pariwisata merupakan sektor yang potensial untuk dikembangkan sebagai salah satu sumber pendapatan daerah. Salah satu kunci keberhasilan dari kegiatan pariwisata adalah potensi yang dimiliki dari objek wisata tersebut sebagai daya tarik bagi wisatawan untuk berkunjung, baik wisatawan Nusantara maupun Mancanegara. Salah satu potensi wisata yang menjadi daya tarik sebagai destinasi yang diminati wisatawan adalah wisata alam.

Objek wisata alam yang menarik di Indonesia sangat banyak sekali, salah satu objek yang dipilih adalah danau Picung yang merupakan objek wisata alam yang terletak di kabupaten rejang lebong provinsi Bengkulu yang memiliki keindahan alam yang sangat menarik dengan luas $200 \mathrm{Ha}$. Wisata alam merupakan suatu kegiatan perjalanan atau sebagian dari kegiatan tersebut yang dilakukan secara sukarela serta bersifat sementara untuk menikmati gejala keunikan dan keindahan alam Taman Nasional, Taman Hutan Raya, Taman Wisata Alam, Taman Buru, Hutan Lindung, dan Hutan Produksi [1]. Menurut Rusita obyek wisata alam yang tersebar di laut, pantai, hutan dan pegunungan adalah produk-produk potensial yang dapat dikembangkan untuk kegiatan wisata alam [2].

Produk wisata sebagai salah satu objek penawaran dalam pemasaran pariwisata memiliki unsur-unsur dalam pemasaran pariwisata utama yang terdiri dari 3 bagian yaitu [3]:

a. Atraksi atau daya tarik daerah tujuan wisata, termasuk di dalamnya citra yang dibayangkan oleh wisatawan.

b. Amenitas atau fasilitas yang dimiliki daerah tujuan wisata, meliputi akomodasi, usaha pengolahan makanan, parkir, transportasi, rekreasi, dan lain-lain.

c. Aksesibilitas atau kemudahan untuk mencapai daerah tujuan wisata tersebut.

Marpaung mengemukakan bahwa obyek dan daya tarik wisata adalah suatu bentukan dan/atau aktivitas dan fasilitas yang berhubungan serta dapat menarik minatwisatawan atau pengunjung untuk datang ke suatu daerah/tempat tertentu [4].

Unsur-unsur paling penting yang menjadi daya tarik dari sebuah daerah tujuan ekowisata menurut Sudarto adalah kondisi alamnya, kondisi flora dan fauna yang unik, langka dan endemik, kondisi fenomena alamnya, kondisi adat dan budaya [5].

Pengertian tentang wisata alam mengalami perkembangan dari waktu ke waktu. Namun pada hakekatnya, pengertian ekowisata adalah suatu bentuk wisata yang bertanggung jawab terhadap kelestarian area yang masih alami, memberi manfaat secara ekonomi dan mempertahankan keutuhan budaya masyarakat setempat [6]. Menurut PHPA kegiatan wisata alam di dalam kawasan konservasi diarahkan pada upaya pendayagunaan potensi obyek wisata alam dengan tetap memperhatikan prinsip keseimbangan antara kepentingan pemanfaatan dan pelestarian alam [7].

Obyek wisata alam bisa berupa gunung, lembah, sungai, pesisir, laut, pulau, air terjun, danau, lembah sempit (canyon), rimba, gua dan sebagainya [8]. Edward Inskeep membagi daya tarik dan kegiatan wisata dalam 3 kategori, yaitu [9]:

a. Daya tarik alam, yang meliputi iklim, keindahan alam, pantai, flora dan fauna, karakter khas lingkungan, taman dan kawasan konservasi, serta wisata kesehatan,

b. Daya tarik budaya, yang meliputi tapak arkeologis, kesejahteraan dan kebudayaan, pola-pola kebudayaan yang khas, kesenian dan kerajinan, kegiatan ekonomi khas, kawasan perkotaan spesifik, fasilitas budaya dan museum, festival budaya, serta keramahtamahan masyarakat penghuni,

c. Daya tarik khusus, atau kadang disebut daya tarik buatan. Meliputi theme parks, amusement parks dan sirkus, wisata belanja, MICE (meetings, incentive conventions, and exhibitions), events khusus, perjudian, hiburan, serta rekreasi dan olahraga.

Objek wisata alam danau Picung dilihat dari produk wisata (atraksi, amenitas, aksesibilitas) masih belum berkembang dengan baik. Hal ini bisa dilihat dari pola penataan fasilitas sarana dan prasarana belum tertata dengan baik serta jumlah nya masih sangat sedikit sehingga kunjungan wisatawan belum maksimal. Terkait permasalahan di atas, maka diperlukan suatu upaya kajian atau identifikasi dalam rangka untuk tetap melestarikan kondisi lingkungan alam di danau Picung yang memiliki potensi yang sangat besar untuk dikembangkan sebagai objek dan daya tarik wisata alam ditinjau dari aspek produk wisata. Penelitian ini bertujuan untuk mengetahui potensi obyek 
wisata alam danau Picung ditinjau dari aspek produk wisata, menganalisis strategi pengembangan objek wisata alam danau Picung terkait aspek produk wisata, dan mengetahui rencana pengembangan dan arahan desain zonasi kawasan objek wisata alam Danau Picung.

\section{METODE PENELITIAN}

Metoda yang digunakan dalam penulisan ini adalah deskriptif kualitatif. Analisis yang digunakan dalam penelitian ini adalah analisis SWOT (strenght, weakness, opportunity, theart). Hasil dari analisis ini untuk mengetahui strategi dan program pegembangan serta arahan desain zonasi potensi kawasan wisata Alam danau Picung ditinjau dari aspek produk wisata.

\section{Metode Pengumpulan Data}

Metoda pengumpulan data dilakukan dengan mencari studi literatur yang berkaitan dengan teori tentang wisata alam dan produk wisata. Data primer terkait dengan kondisi eksisting di objek wisata alam danau Picung diperoleh dengan melakukan observasi dan dokumentasi lapangan.

\section{Metode Analisis Data}

Penelitian ini untuk melihat potensi objek wisata alam danau Picung berdasarkan kondisi eksisting kemudian dikaitkan dengan tinjauan teori. Setelah mendapatkan data baik primer maupun sekunder akan dilakukan analisis untuk memndapatkan kesimpulan dan rekomendasi arahan pengembangan desain zonasi kawasan objek wisata alam danau Picung ditinjau dari aspek produk wisata (atraksi, aksesibilitas, dan amenitas).

\section{Lokasi Penelitian}

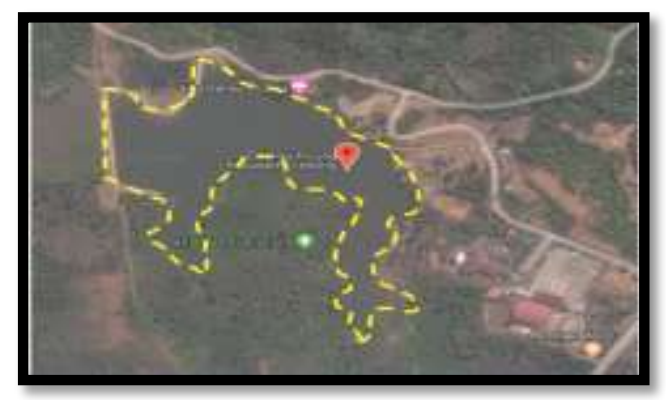

Gambar 1. Peta Citra Satelit Kawasan Wisata Alam Danau Picung Muara aman, Kabupaten Lebong Provinsi Bengkulu

(Sumber : Dokumentasi Pribadi, 2018)

\section{Kondisi Eksisting}

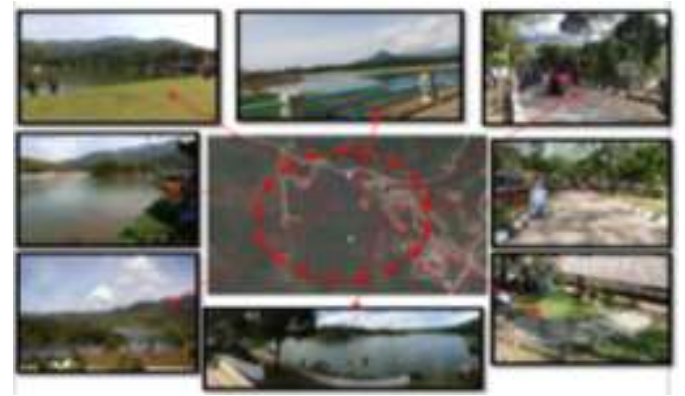

Gambar 2. Kondisi Eksisting Kawasan Wisata Alam Danau Picung Muara aman, Kabupaten Lebong Provinsi Bengkulu

(Sumber : Dokumen Pribadi,2018)

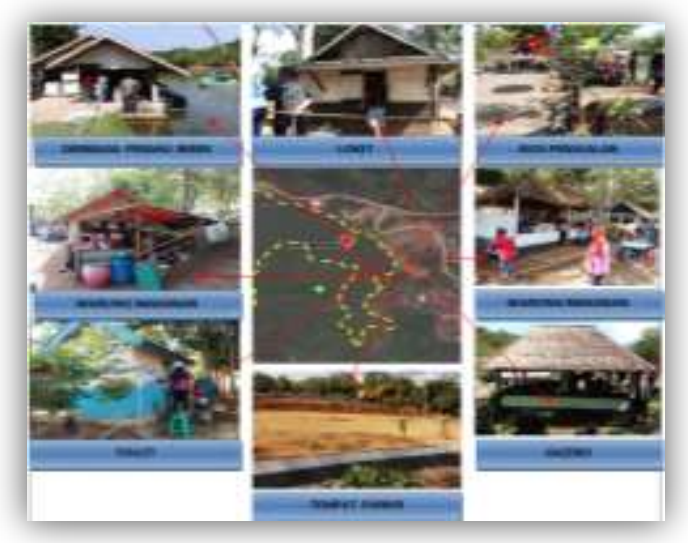

Gambar 3. Kondisi Eksisting Amenitas Kawasan Wisata Alam Danau Picung Muara aman, Kabupaten Lebong Provinsi Bengkulu

(Sumber : Dokumen Pribadi,2018)

Amenitas dalam objek wisata merupakan komponen yang sangat penting dalam pengembangan destinasi wisata ke depannya. Amenitas merupakan bagian dari fasilitas pendukung pemenuhan kebutuhan fisik dasar wisatawan. Fasilitas yang ada di objek wisata danau Picung bisa dilihat pada gambar di atas yaitu loket, warung makanan, kios penjualan, gazebo, toilet, dermaga, parkir motor dan mobil. Kondisi fisik nya masih belum terlihat maksimal dan belum layak untuk wisatawan. Jumlah toilet hanya ada satu sehingga belum memenuhi standar kebutuhan wisatawan sesuai dengan jumlah kunjungan wisatawan. Fasilitas-fasilitas pendukung lainnya seperti restoran, hotel/resort/penginapan, pusat informasi, mushola, kios souvenir belum tersedia sehingga objek wisata danau Picung belum bisa dijadikan destinasi wisata alam unggulan. 


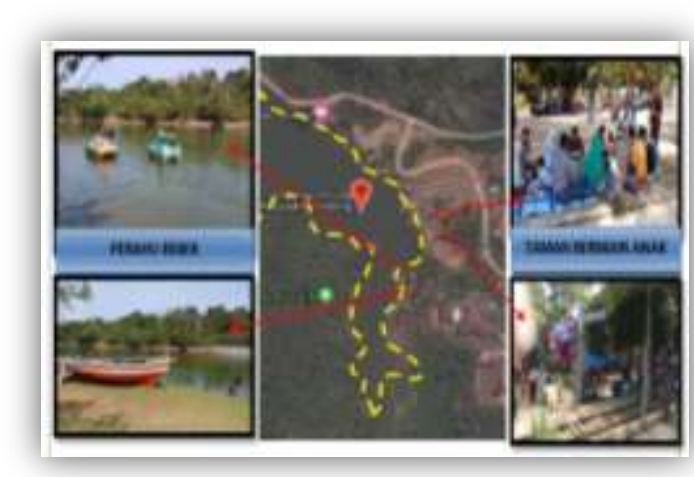

Gambar 4. Kondisi Eksisting Atraksi Kawasan Wisata Alam Danau Picung Muara aman, Kabupaten Lebong Provinsi Bengkulu (Sumber : Dokumen Pribadi,2018)

Atraksi dalam produk wisata dibagi menjadi 3 bagian, yaitu atraksi alam, atraksi buatan, dan atraksi budaya. Danau picung hanya memiliki atraksi buatan, seperti taman bermain anak, wahana air perahu bebek. Hal ini bisa dilihat pada gambar di atas dengan kedua atraksi ini kondisi nya belum maksimal. Sedangkan atraksi alam hanya keindahan alam yang bisa dilihat belum ada tempat yang memanfaatkan agrowisata, pemeliharaan fauna yang bisa dijadikan objek wisata. Wisata budaya juga belum tersedia, seperti festival budaya, kesenian dan kerajinan khas daerah, museum, keramahtamahan masyarakat penghuni.

\section{HASIL DAN PEMBAHASAN}

\section{Analisis SWOT}

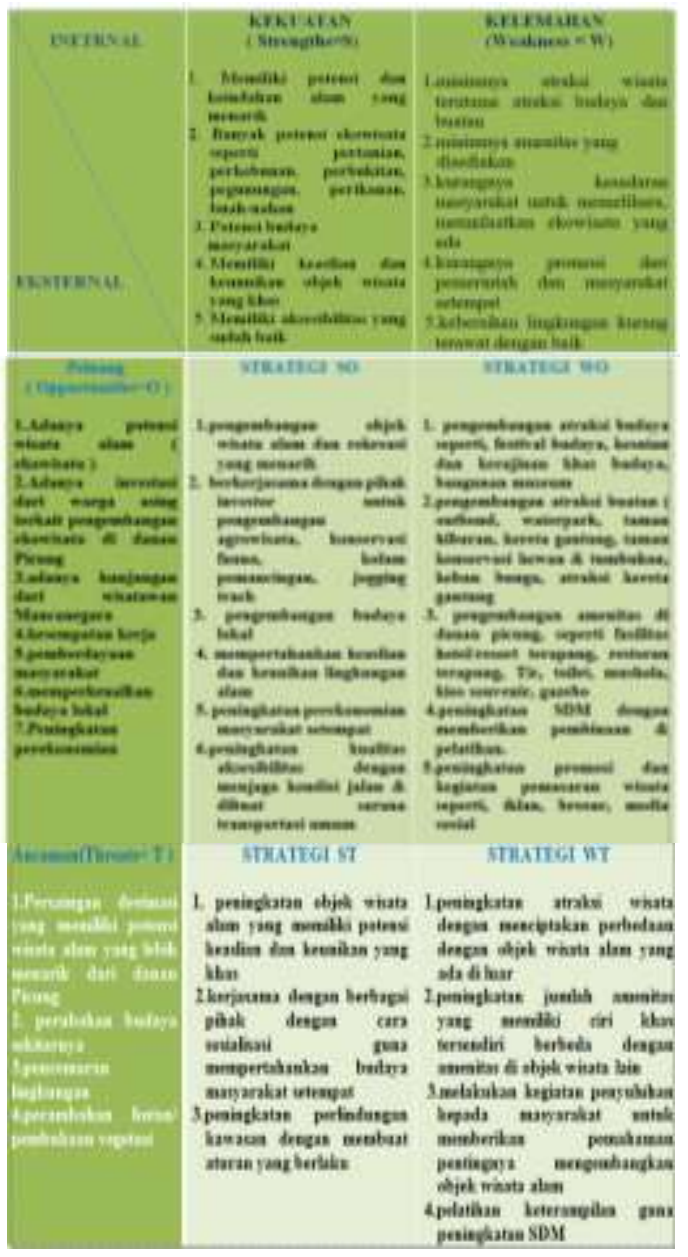




\section{Strategi dan Program Pengembangan Wisata Alam Danau Picung Terkait Aspek Produk Wisata}

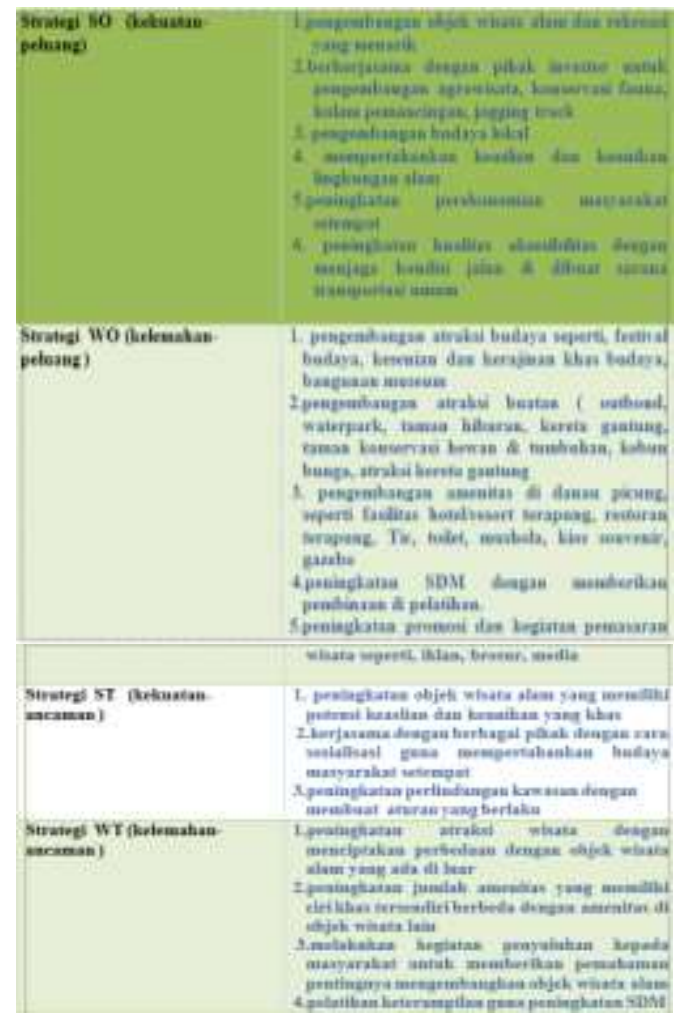

\section{PROGRAM PENGEMBANGAN PRODUK WISATA}

\section{Atraksi}

Program pengembangan produk wisata atraksi meliputi atraksi alam, atraksi buatan, dan atraksi budaya.

a. Atraksi alam: pengembangan atraksi alam yang memiliki keaslian dan keunikan yang khas (memelihara ekosistem yang ada seperti vegetasi, perbukitan, pegunungan, flora dan fauna).

b. Atraksi buatan: pengembangan dan perencanaan atraksi wisata agro, wisata fauna (Kebun binatang, kolam pemancingan), outbond, waterpark, taman hiburan, taman bunga, atraksi kereta gantung, perahu bebek

c. Atraksi Budaya: pengembangan dan perencanaan festival budaya, kesenian dan kerajinan khas budaya khas rejang lebong, bangunan museum

\section{Amenitas}

Pengembangan dan perencanaan fasilitas hotel/resort terapung, restoran terapung, Tic, toilet, mushola, kios souvenir, gazebo, dan loket.

\begin{abstract}
Aksesibilitas
Peningkatan kualitas aksesibilitas dengan menjaga kondisi jalan dan dibuat sarana transportasi umum
\end{abstract}

\section{RENCANA ZONASI KAWASAN DANAU PICUNG}

\section{Atraksi}

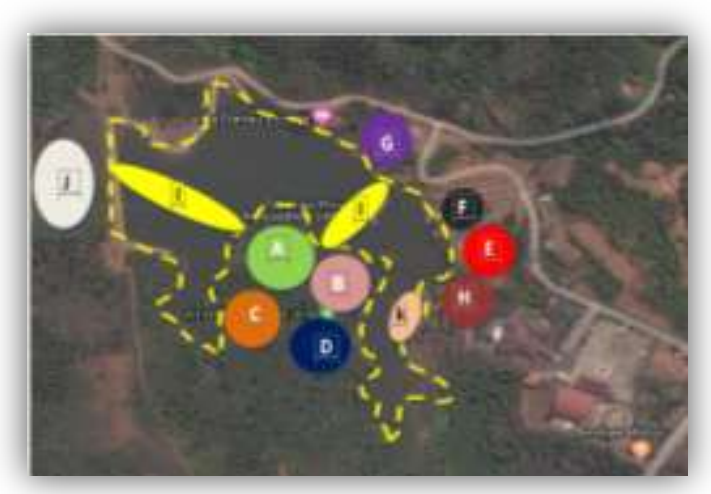

Gambar 5. Rencana Pengembangan zonasi Atraksi Wisata Alam Danau Picung Muara aman, Kabupaten Lebong Provinsi Bengkulu Sumber : Analisis, 2018

Keterangan:

\begin{tabular}{|c|c|}
\hline$A=Z$ ese thats Agn & d = Zase Waterpath \\
\hline B-Zlea Kobun Levitury & H-Zina Butgenso muroum \\
\hline 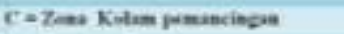 & I = Zous Kersts Gastanz \\
\hline D-2eex Owitiend & 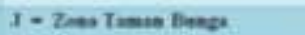 \\
\hline 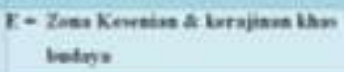 & K-Zens Dermage Furabu hebek \\
\hline$Y=Z$ Zes tums relirnai & \\
\hline
\end{tabular}

\section{Amenitas}

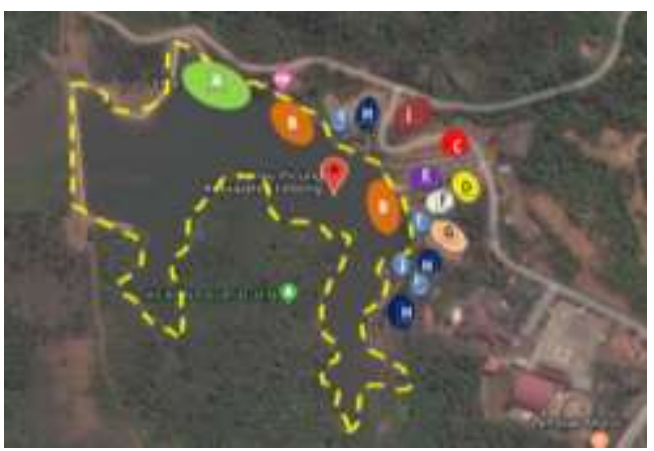

Gambar 6. Rencana Pengembangan Amenitas zonasi Amenitas Wisata Alam Danau Picung Muara aman, Kabupaten Lebong Provinsi Bengkulu ( Sumber : Analisis, 2018)

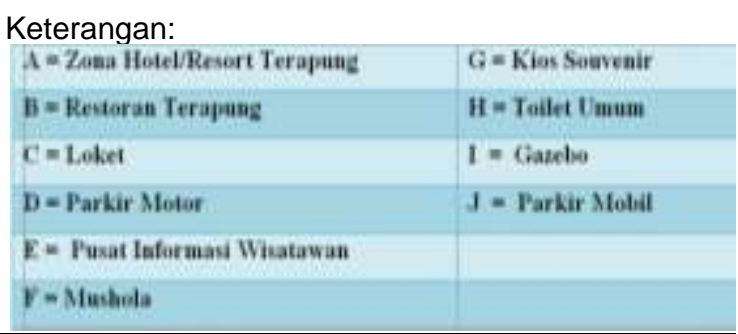




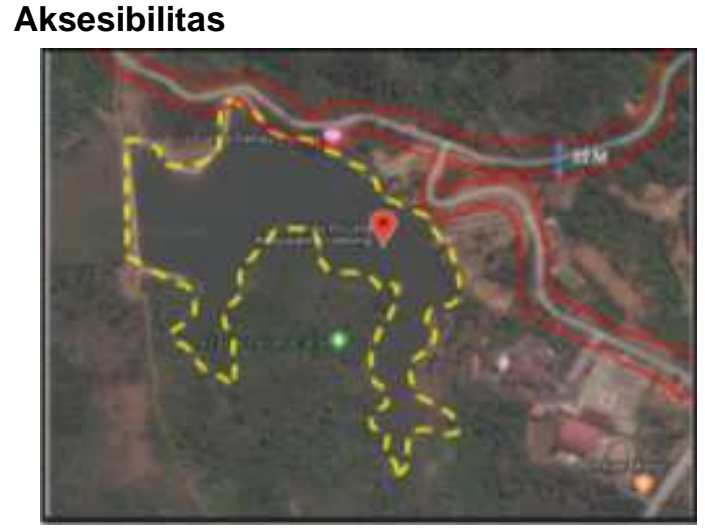

Gambar 7. Rencana Pengembangan zonasi Atraksi Wisata Alam Danau Picung Muara aman, Kabupaten Lebong Provinsi Bengkulu (Sumber : Analisis, 2018)

Akses jalan menuju danau Picung sudah cukup baik, dan hanya bisa di akses dengan jalur darat. Sebaiknya perlu dilakukan sedikit pelebaran sekitar $10 \mathrm{~m}$ untuk kenyamanan pengunjung baik yang membawa kendaraan roda empat maupun roda dua. Untuk mempermudah menuju objek wisata sebaiknya diadakan transportasi umum untuk pengunjung yang tidak mempunyai kendaraan pribadi.

\section{KESIMPULAN}

Potensi yang bisa dikembangkan di danau Picung adalah sebagai wisata alam dan rekreasi yang memiliki keindahan dan keunikan alam yang menarik.

Strategi pengembangan kawasan wisata alam danau Picung dengan peningkatan atraksi budaya, atraksi buatan, dan atraksi alam serta amenitas yang memiliki potensi keaslian dan keunikan yang menarik dari objek wisata lain harus di dukung dengan peningkatan SDM di daerah sekitar kawasan objek wisata dengan memberikan pembinaan dan pelatihan sehingga bisa meningkatkan kompetensi dan perekonomian mayarakat. Selain itu, peningkatan dan pengembangan budaya lokal juga harus terus dipertahankan dengan membuat aturan yang berlaku Strategi pengembangan yang juga harus dilakukan adalah dengan pengembangan dan peningkatan kegiatan pemasaran seperti promosi dengan berkerjasama dengan pihak Pemerintah, investor, dan masyarakat sehingga wisata alam danau Picung lebih dikenal wisatawan.

\section{UCAPAN TERIMA KASIH}

Dalam penulisan dan penyelesaian penelitian ini tidak terlepas dukungan dari berbagai pihak. Peneliti secara khusus mengucapkan terima kasih yang sebesar-besarnya kepada semua pihak yang telah membantu khususnya kepada instansi Universitas Sriwijaya Palembang yang telah memberikan kontribusi dana kepada peneliti, sehingga penelitian ini bisa diselesaikan dengan tepat waktu, lancar dan tidak ada halangan satu apapun.

Nomor Surat Kontrak penelitian 0179.213/UN9/SB3.LP2M.PT/2018

\section{DAFTAR PUSTAKA}

[1] Direktorat Pemanfaatan Alam dan Jasa Lingkungan. (2002).

[2] Rusita, Walimbo Rachmat, sari yunita, and yanti melda. (2016). Studi Potensi Objek Dan Daya Tarik Wisata Alam Air Teriun Wiyono Di Taman Hutan Raya Wan Abdul Rahman, Provinsi Lampung. 17:165-186.

[3] Yoeti, Oka A. (2008). Perencanaan dan Pengembangan Pariwisata. PT. Pradnya Paramita. Jakarta.

[4] Marpaung, Happy. (2000). Pengetahuan Pariwisata.Bandung: Alfabeta

[5] Sudarto, G. (1999). Ekowisata: Wahana Pelestarian Alam, Pengembangan Ekonomi Berkelanjutan, dan Pemberdayaan Masyarakat. Yayasan Kalpataru Bahari. Bekasi.

[6] Fandeli, C. (2005). Pengembangan Ekowisata Berbasis Konservasi di Taman Nasional.Jakarta

[7] PHPA Perlindungan Hutan dan Pelestarian Alam. (1996). Pola Pengelolaan Kawasan Suaka Alam, Kawasan Pelestarian Alam, Taman Wisata Alam dan Hutan Lindung. Direktorat Jenderal Perlindungan Hutan dan Pelestarian Alam. Bogor.

[8] Ko, R. K .T. (2001). Obyek Wisata Alam : Pedoman Identifikasi, Pengembangan, Pengelolaan, Pemeliharaan dan Pemasaran. Yayasan Buena Vista. Bogor.

[9] Inskeep, Edward. (1991). Tourism Planning: An Integrated and Sustainable Developmnt Approach. New York: Van Nostrand Reinhold. 